\title{
Jurisprudentie
}

\section{Rechtspraak; nemo tenetur en de smartphone}

\author{
Noot bij Rb. Noord-Holland 28 februari 2019, ECLI:NL:RBNHO:2019:1568
}

Mr. dr. J.S. Nan*

1. Op 28 februari 2019 heeft de Rechtbank NoordHolland bepaald dat het opsporingsambtenaren was toegestaan de duim van een geboeide verdachte ter ontgrendeling op diens iPhone te plaatsen. ${ }^{1}$ 'Justitie' was op zoek naar 'in' de telefoon gelegen bewijs in een onderzoek naar diverse vermogensdelicten (zoals 'phishing' en oplichting) en deelname aan een criminele organisatie. De verdachte wenste niet mee te werken aan de ontgrendeling van zijn telefoon. Niet geheel onbegrijpelijk werd in de uiteindelijke strafzaak onder meer naar voren gebracht dat het aldus verkregen bewijs niet mocht worden gebruikt tegen de verdachte, daar in strijd met het nemo tenetur-beginsel en de beginselen van proportionaliteit en subsidiariteit zou zijn gehandeld. De verdediging werd in haar betoog echter niet gevolgd.

2. De rechtbank overwoog dat de gewraakte handelwijze niet in strijd was met het nemo tenetur-beginsel. Dat beginsel houdt volgens haar eerst en vooral in dat de verdachte mag zwijgen als hij dat wil. De verdachte heeft in casu niets hoeven verklaren of actief ergens aan moeten meewerken, maar heeft slechts de onderzoekshandeling moeten dulden. Hierbij is een zeer geringe mate van dwang toegepast (de aangekondigde toepassing van gepast geweld bleef uit, kennelijk berustte de verdachte

* Mr. dr. J.S. Nan is universitair hoofddocent Straf(proces)recht aan de Erasmus Universiteit Rotterdam, cassatieadvocaat bij Wladimiroff Advocaten, Den Haag en tevens redacteur van dit tijdschrift.

1. Rechtbank Noord-Holland 28 februari 2019, ECLI:NL:RBNHO: 2019:1568. toen het eenmaal zo ver was). Het maakt voor de rechtbank niet uit dat hierdoor wilsafhankelijk en voor de verdachte belastende gegevens werden verkregen. Ook de beginselen van proportionaliteit en subsidiariteit waren volgens de rechtbank niet geschonden. Voor haar was met name van belang dat via toegang tot de telefoon de opsporing kon verwachten relevante gegevens te vergaren, de telefoon nieuw en (nog) niet te kraken was, het ging om een verdenking van ernstige strafbare feiten en slechts in beperkte mate inbreuk is gemaakt op de lichamelijke integriteit van de verdachte.

3. De vraag is hoe deze uitspraak te waarderen. Mag een verdachte fysiek inderdaad gedwongen worden met een lichaamskenmerk bewijs tegen zichzelf te ontsluiten? Onmiddellijk doemt een vergelijking met de zaak Saunders op. Van de verdachte mogen immers onder andere DNA-materiaal, adem-, bloed- en urinemonsters worden afgenomen tegen zijn wil in. ${ }^{2}$ Maar zo gemakkelijk is de vraag toch niet te beantwoorden, waarbij ook zij verwezen naar de discussie tussen Bood enerzijds en diverse auteurs anderzijds. ${ }^{3}$ Ook bij het verkrijgen van

2. EHRM 17 december 1996, ECLI:CE:ECHR:1996:1217JUD001918791, par. 69 (Saunders/Verenigd Koninkrijk). In richtlijn 2016/343/EU (aangaande de onschuldpresumptie), wordt hierbij aangesloten (zie preambule, 27-29).

3. A. Bood, 'Geef ze een vinger... Gedwongen ontgrendeling van een smartphone en het nemo tenetur-beginsel', NJB 2018/1880, afl. 36, p. 2744-2748. Daartegenover stonden L. Stevens, 'Gedwongen biometrische toegangsverschaffing is niet in strijd met nemo tenetur', NJB 2019/315, afl. 6, p. 400-403; M. Egberts \& W. Ferdinandusse, 'Reactie op Alex Bood', NJB 2019/316, afl. 6, p. 404 en D. van Toor, 'Het gedwongen ontgrendelen van een smartphone in het licht van het 
zogeheten wilsonafhankelijk (bewijs)materiaal kan namelijk een probleem met het nemo tenetur-beginsel rijzen. Voor een goed begrip van dit diffuse beginsel zij daarom eerst de standaardopvattingen van het EHRM gegeven, zoals recent nog een op een rij gezet in de zaak Ibrahim en anderen. ${ }^{4}$ Het recht van de verdachte om zichzelf niet te hoeven belasten betekent hoofdzakelijk:

'respecting the will of an accused person to remain silent and presupposes that the prosecution in a criminal case seek to prove their case without resort to evidence obtained through methods of coercion or oppression in defiance of the will of the accused.'

Natuurlijk heeft de overheid een belang bij het bestrijden van criminaliteit en mag zij daartoe activiteiten ontplooien. Maar onbehoorlijke activiteiten zijn daarbij - natuurlijk - niet toegestaan. De gedachte achter dit recht is namelijk dat het, samen met het recht om te zwijgen, de verdachte beschermt tegen 'improper compulsion', zodat 'miscarriages of justice' kunnen worden voorkomen en de doelen van artikel 6 EVRM kunnen worden bereikt. Van opsporing en vervolging tegen elke prijs kan dus geen sprake zijn volgens het Straatsburgse Hof. Het nemo tenetur-beginsel en het zwijgrecht garanderen dat de verdachte zelf kan bepalen of hij iets wil verklaren en zo ja, wat dan. Daarom is het zo belangrijk dat de verdachte tijdig van deze rechten op de hoogte geraakt, doordat hij in een vroeg stadium toegang heeft tot een raadsman die hem hierover inlicht (of door notificatie door de autoriteiten). Het EHRM onderscheidt drie situaties in het bijzonder waarin sprake kan zijn van ongeoorloofde dwang (Ibrahim, par. 267):

'The first is where a suspect is obliged to testify under threat of sanctions and either testifies in consequence $(. .$.$) or is sanctioned for refusing to$ testify $(\ldots)$. The second is where physical or psychological pressure, often in the form of treatment which breaches Article 3 of the Convention, is applied to obtain real evidence or statements (...). The third is where the authorities use subterfuge to elicit information that they were unable to obtain during questioning.'

nemo-teneturbeginsel. Reactie op Boods "Geef ze een vinger ..."', NJB 2019/317, afl. 6, p. 405-407. Zie ook S.L.T.J. Ligthart, 'Het recht tegen zelfincriminatie ex artikel 6 EVRM. Doorwerking van het nemo teneturbeginsel in enkele gedachte-experimenten volgens de benadering van het EHRM en van de Hoge Raad', DD 2019/16. Zie ten slotte ook A. Bood, 'Naschrift', NJB 2019/318, afl. 6, p. 408-409.

4. EHRM 13 september 2016, ECLI:CE:ECHR:2016:0913JUD005054108, par. 266-269 (Ibrahim e.a./Verenigd Koninkrijk). Zie eerder al EHRM 10 maart 2009, ECLI:CE:ECHR:2009:0310JUD000437802, par. 88-93 (Bykov/Rusland) (Grote Kamer); EHRM 29 juni 2007, ECLI:CE:ECHR: 2007:0629JUD001580902, par. 53-63 (O'Halloran en Francis/ Verenigd Koninkrijk) (Grote Kamer) en EHRM 11 juli 2006, ECLI:CE:ECHR:2006:0711JUD005481000, par. 94-102 (Jalloh/Duitsland) (Grote Kamer).
Het EHRM bekijkt ten aanzien van het recht van de verdachte om zichzelf niet te belasten uiteindelijk of dat in essentie is gewaarborgd in het concrete geval ('whether a procedure has extinguished the very essence of the privilege against self-incrimination'). Daarvoor heeft het EHRM in het bijzonder drie factoren onderkend: 'the nature and degree of the compulsion, the existence of any relevant safeguards in the procedures and the use to which any material so obtained is put'. ${ }^{5}$ Met Van Toor kan worden gezegd dat het nemo tenetur-beginsel beschermt tegen elke onoorbare dwang om via de verdachte tegen diens wil in bewijs te verkrijgen en te gebruiken en dat het beginsel dus means based is en niet (zozeer) material based. ${ }^{6}$ De gelding van het beginsel is het sterkst in het domein van het klassieke strafrecht. Daarbuiten neemt de bescherming soms (danig) af en is zeker een inlichtingenplicht ook voor het EHRM op zich geen vies woord, zij het dat de betrokkene zich ook dan niet vrijwillig volledig hoeft over te leveren aan de bestraffende overheid. Evenmin kunnen de wél verschafte inlichtingen een-op-een gebruikt worden in punitieve procedures. Bijzondere categorieën zijn in dat verband het fiscale recht en het verkeersstrafrecht. ${ }^{7}$

4. De Hoge Raad vaart een iets andere koers, die heel sterk is geënt op Saunders en de aard van het te verkrijgen bewijsmateriaal; wilsafhankelijk of wilsonafhankelijk. Het eerste is niet bruikbaar in een punitieve procedure tegen de betrokkene, het tweede wel. ${ }^{8}$ Daarbij is van belang dat de Hoge Raad overwoog dat 'de kwalificatie van materiaal als "wilsonafhankelijk" dan wel "wilsafhankelijk" - welk onderscheid samenhangt met het zwijgrecht van de betrokkene - verbonden [is] aan de aard van het materiaal (of het in fysieke zin "bestaat" onafhankelijk van de wil van de betrokkene).' Een vaste overweging van de Hoge Raad is voorts dat de enkele grond dat de medewerking van de verdachte nodig is om documenten te verkrijgen waarin een verklaring van de verdachte is vervat, nog niet maakt dat die documenten als wilsafhankelijk

5. Zie bijvoorbeeld EHRM 10 maart 2009, ECLI:CE:ECHR: 2009:0310JUD000437802 (Bykov/Rusland) (Grote Kamer), par. 104.

6. Zie onder andere D.A.G. van Toor, 'Het nemo-teneturbeginsel in de conceptwetsvoorstellen van het Wetboek van Strafvordering', TBS\&H 2018-4, p. 249-254

7. Hierover D.A.G. van Toor, 'Het nemo-teneturbeginsel. Rechtspraak van het Europese Hof voor de Rechten van de Mens en de Hoge Raad vergeleken', TBS\&H 2016-1, p. 28-43. Zie uiteraard de bekende fiscale zaken EHRM 25 februari 1993, ECLI:CE:ECHR: 1993:0225JUD001082884 (Funke/Frankrijk); EHRM 3 augustus 2001, ECLI:CE:ECHR:2001:0503JUD003182796 (J.B./Zwitserland) en EHRM 5 juli 2012, ECLI:CE:ECHR:2012:0405JUD001166304 (Chambaz/ Zwiters(and). Zie ook L.C.A. Wijsman, Nemo tenetur in belastingzaken (diss. Rotterdam), 2017.

8. HR 24 april 2015, ECLI:NL:HR:2015:1137 (civiele zaak) en HR 12 juli 2013, ECLI:NL:HR:2013:BZ3640, NJ 2013/435, m.nt. J.W. Zwemmer (civiele zaak). Over de insteek van het EHRM ten opzichte van de Hoge Raad, D.A.G. van Toor, 'Het nemo-teneturbeginsel. Rechtspraak van het Europese Hof voor de Rechten van de Mens en de Hoge Raad vergeleken', TBS\&H 2016-1, p. 28-43. 
bewijsmateriaal moeten worden aangemerkt. ${ }^{9}$ Zie overigens ook nog HR 14 juni 2016, ECLI:NL:HR:NL:2016:1200, N7 2016/364, m.nt. T. Kooijmans. Daarin herhaalde de Hoge Raad dat de bevoegdheid om een voorwerp in beslag te nemen, ook de bevoegdheid omvat tot het desnoods tegen de wil van de betrokkene en met proportioneel geweld openen van diens vuist.

5. De uitleg van het nemo tenetur-beginsel van het EHRM is, zoals uit het voorgaande al bleek, ruimer. Het EHRM beziet immers uiteindelijk of, niettegenstaande het belang van criminaliteitsbestrijding, de wijze van verkrijging door de beugel kan, of het nu gaat om wilsafhankelijk of wilsonafhankelijk materiaal. De aard van het materiaal maakt daarbij wél uit voor de mate van druk die is toegestaan. Bij wilsafhankelijk materiaal is slechts enige pressie mogelijk. In een verhoor mag de (zwijgende) verdachte best het vuur aan de schenen worden gelegd en er mag bijvoorbeeld een informant bij hem worden geplaatst (bijvoorbeeld op cel). Maar de verklaringsvrijheid van de verdachte mag daardoor evenwel niet 'vernietigd' worden (met name te beoordelen aan de hand van de drie hiervoor vermelde factoren). Dat kan het geval zijn door (fysieke) druk (de verhorende agenten mogen de schenen van de verdachte niet breken om hem te laten verklaren) of door een kunstgreep die in feite neerkomt op een verhoor (maar dan zonder de daarmee omgeven waarborgen, zoals een politie-informant die in de gevangenis aanhoudend het gesprek op de tegen de zich op zijn zwijgrecht beroepende verdachte lopende strafzaak stuurt). ${ }^{10} \mathrm{Bij}$ materiaal dat onafhankelijk van de wil van de verdachte bestaat is (veel) meer dwang toegestaan, maar ook dan kan een onbehoorlijke wijze van verkrijging alsnog voor problemen zorgen. Wederom komt het dan in het bijzonder aan op de aard en omvang van de dwang waardoor het 'real evidence' is verkregen, de procedurele waarborgen waarmee de toepassing van de bevoegdheid omgeven is geweest en het uiteindelijke gebruik van dat bewijs. In de zaak Jalloh werd een verdachte die (een bescheiden hoeveelheid) drugs had ingeslikt door vier politieagenten vastgehouden en werden hem medicamenten toegediend (onder andere via een slang door zijn neus naar zijn maag) om hem te laten overgeven. $\mathrm{Nu}$ bij de veroordeling de aldus verkregen drugs het doorslaggevende bewijs tegen Jalloh waren, achtte het EHRM niet alleen artikel 3 EVRM, maar ook artikel 6 EVRM geschonden. Het recht om zichzelf niet te hoeven belasten was in essentie tenietgedaan. ${ }^{11}$ Deze uitspraak laat zien dat het nemo tenetur-beginsel niet louter een bewijsbeginsel is, maar dat hierin ook een element van bescherming zit tegen onbehoorlijk optreden van de (vervolgende) overheid. De verdachte is in die zin niet vogelvrij. Aan het beginsel zit dus, net als aan de onschuldpresumptie, ook een bejegeningscomponent.

6. En dan komen we weer bij de onderhavige uitspraak. Het nemo tenetur-beginsel laat de verdachte hoofdzakelijk de ruimte om zelf te bepalen of hij en wat hij wil verklaren. Iets breder bezien wordt de verdachte beschermd tegen elke onbehoorlijke wijze van bewijsverkrijging (en daaropvolgend gebruik in een punitieve procedure), zodra van het recht om niet aan de eigen veroordeling mee te werken (preciezer: om niet tegen zichzelf te hoeven produceren), door de toepaste pressie op de keper beschouwd niets overblijft. In de Haarlemse zaak ging het om het afdwingen, zo nodig met gepast geweld, van medewerking van de verdachte aan het ontgrendelen van diens telefoon (zodat deze kon worden onderzocht). De verklaringsvrijheid van de verdachte is gerespecteerd (hij heeft niets hoeven zeggen, alleen iets moeten dulden) en de gang van zaken kan niet worden getypeerd als onbehoorlijk (hoe anders in de zaak Jalloh). Wat met de vingerafdruk van de verdachte via diens telefoon kon worden ontsloten (een andere manier was er nog niet), was al geproduceerd - ook voor zover het vanuit de verdachte was opgesteld. Met andere woorden, ook verklaringen of gegevens die oorspronkelijk van zijn wil afhankelijk waren (berichten, notities e.d.), bestonden al en kunnen niet (langer) als wilsafhankelijk worden beschouwd. Ze hoefden, net als het recht, alleen nog maar gevonden te worden. Sprake was ten slotte van een verdenking van ernstige strafbare feiten. De overheid had dus voldoende belang bij de opsporing en vervolging daarvan.

7. Mijn conclusie is dat het nemo tenetur-beginsel zich niet uitstrekte tot het verkregen bewijs via de afgedwongen ontgrendeling van de telefoon van de verdachte en dat de wijze van verkrijging dat in casu niet anders maakt. Deze uitspraak is wat mij betreft dan ook juist gelet op het positieve recht. Hoger beroep werd, zo heb ik inmiddels begrepen, niet ingesteld. 